\title{
Accounting Behaviour of Small Scale Enterprises in Nigeria: Focus on Business Sustainability and Growth
}

\author{
Akabom Ita Asuquo, Ejabu Fidelis Enya, Bogbo Regina Jaka, Atu Otuba Akung, \\ Adejonpe Anthony Olayinka
}

Department of Accounting, Faculty of Management Sciences, University of Calabar, Calabar, Nigeria

\section{Email address:}

drakabom3@gmail.com (A. I. Asuquo), ejabufidelis@yahoo.com (E. F. Enya), ginabogbo11@yahoo.com (B. R. Jaka), otubaetta@yahoo.com (A. O. Akung), adejonpea@gmail (A. A. Olayinka)

\section{To cite this article:}

Akabom Ita Asuquo, Ejabu Fidelis Enya, Bogbo Regina Jaka, Atu Otuba Akung, Adejonpe Anthony Olayinka. Accounting Behaviour of Small Scale Enterprises in Nigeria: Focus on Business Sustainability and Growth. Journal of Business and Economic Development. Vol. 3, No. 2, 2018, pp. 43-50. doi: 10.11648/j.jbed.20180302.12

Received: May 24, 2018; Accepted: June 21, 2018; Published: July 12, 2018

\begin{abstract}
Accounting practice provides a window to evaluate performance and determine sustainability of an entity. This study examined accounting behaviour of small and medium enterprises focus on sustainability and growth. The study adopted survey research design and questionnaire was structured into 4 points likert scale, responses through stratified random sampling were collated. Data gathered were analysed using descriptive statistics, paired sample t-test and Pearson's product moment correlation analysis. The results demonstrated that good accounting behaviour enhanced measurement of resources, internal control assessment and growth of SMEs. This study recommended that government and owners of SMEs should collaborate through capacity building in exposing the owners of SMEs to embrace a culture of record keeping so as to enhance sustainability and growth in the economy.
\end{abstract}

Keywords: Accounting Behaviour, Small Scale Enterprise, Business Sustainability and Growth

\section{Introduction}

The involvement of Small and Micro Enterprises (SMEs) to the economic advancement of most developed countries is overpowering. This is because the sector provides reasonable employment to majority of the country population, thereby contributes adequately to the improvement in revenue growth of government. Owners of these enterprises pay income tax, VAT and withholding tax as well as providing income and wages to households. The growth of SMEs in a developing country also contribute significantly to increasing the scope of the direct sector in the economy by reducing poverty rate through fiscal transfers of income from employer to employee. SMEs play important role in the facilitation of social and economic development, its sustainability is a strategy policy of the owner's through a favourable fiscal and monetary policies of the host country. Small and medium enterprise is defined in different perspective ranging from asset base and number of staff /employees which is also connected to their financial status. Central Bank of Nigeria (CBN) describes SMEs as economically self-determine establishments with about 11 to
300 employees and an annual debit turnover of between $\$ 5$ million to $\$ 300$ million. Small business owners contribute significantly in the creation of job opportunities and wealth in Nigeria, its activities has also aided in the growing of the country economy by increasing her GDP. Basically, accounting behaviour is a determining factor of every enterprise sustainability. The reason is that through accounting records, a business enterprise can evaluate her performance over time and ascertain whether profit is maximise or not. Though keeping record of economic transactions appear to be very complex, but the value of accounting systems is quite insightful and relevant in ensuring proper financial management especially in small and medium enterprises. Having a sound accounting system assist SMEs and other business entity in an orderly manner prepare efficient and accurate financial information and control same for business sustainability. However, as a requirement for granting credit facility, funds Providers rely mostly on financial information before considering investment decision as to enable them ascertain the capacity, coverage and make better forecast about the business prospect. This is because most businesses including SMEs have been marked with trend of progress 
miscarriage within short term of operation. A chunk of these miscarriages is due to the many constraints that hinder their successful growth such as lack of managerial capabilities, finance, management moderations, and adequate marketing skills that would give them a reasonable benefit to sustain in operation beyond speculation.

\section{STATEMENT OF THE PROBLEM}

In Nigeria, general challenges confronting most small businesses are linked to sudden failure and limited information on factors that might contribute to business sustainability and growth. A good number of small and medium enterprises cannot afford the intricacy of a thorough accounting structure even if they would have, the accounting system could exist in memory and most times appears in a single entries and incomplete form thereby making it difficult for the tracking of cash flow. Besides, audit of SMEs has demonstrated to be among the most troublesome engagement for professional accountants seemingly due to lack of sound system of internal controls and poor record keeping system in practice. Unless for legal requirements, they barely give grave considerations to sound accounting procedures, yet lack and ineffectiveness of accounting procedures have been liable for early failure of most of them. However, for a business to sustain its operation to a foreseeable future period and contribute to growth, such a business is deemed to keep economic records of event as well as putting up measures to control resources and evaluate performance. The research is prompted in Nigeria context given the relevance of SMEs in economic sustainability and growth and to further explore on the problem of not being able to capture the contribution of this sector effectively.

\section{OBJECTIVES OF STUDY}

The primary objective of this study is to evaluate the sustainability of small scale business enterprises in Nigeria. The specific objectives are;

1. Examine the accounting behaviours of small scale enterprises effect on business sustainability in Nigeria

2. Examine the extent to which accounting behaviours effect on SMEs growth in Nigeria.

RESEARCH QUESTIONS.

In response to the problem and the objectives of this study, this research answers the following questions.

1. What relationship exist between accounting behaviours of small scale enterprises and business sustainability in Nigeria.

2. How do accounting behaviours affects small scale enterprises growth in Nigeria?

HYPOTHESES.

1. Accounting behaviours have no significant effect on the sustainability of small and medium enterprises in Nigeria.

2. There is no relationship between accounting records and SMEs growth in Nigeria.

\section{Literature Review and Theoretical Framework}

Overview of Small and Medium Enterprises in Nigeria.
Generally, small and medium enterprises is classified into three groups: micro, small, and medium enterprises. Around the world, there is no generally acceptable definition of small businesses owing to the complexity and universal multiplicity that characterised it operation. Countries like United States, Britain and many European countries define small and medium scale enterprises In terms of number of employee and turnover [16]. In Nigeria, SME is define base on turnover, number of staff and capital investment. According to [17] SMEs as one that engages less than 50 persons with a capital outlay below N500, 000. The Nigerian Industrial Development Bank (NIDB) defined small-scale enterprises as companies with not more than N750, 000.00 in project cost.

SMEs are faced with many tasks in an unindustrialized markets that impede their progress and long-standing sustainability. About $80 \%$ of small enterprises in Nigeria fail within the first 5 years [4]. However, previous scholars have recognised the impact of small businesses to fiscal expansion. Recent review has shown that small businesses has some elements liable for its failure, circumstance facing these challenges are summarized into ten factors such as poor accounting practices, poor management practices, sloppy bookkeeping, poor market effort, lack of planning, lack of adequate information about business line, excessive spending without records, insufficient qualified labour, high cost of overhead and discounting training, poor knowledge about the market and experiences, poor management practices, sloppy bookkeeping, and poor accounting practices [1]. In a contrary, taxation, lack of managerial skill, inadequate social infrastructure, poor financing were seen as significant challenges confronting small businesses in Port Harcourt between 2012 and 2013 [2]. Businesses in Nigeria are seriously crippled by the nature of power supply across all sectors of the economy including businesses, households, and even government. Having constant power supply is vital for the set-ups of small and medium scale enterprises. Power failure adversely affect small businesses and large companies operations and could cause their untimely exit to other countries of the world. Nigeria when matched extremely with other low-income states, like Egypt, Argentina and Brazil, power outage contribute majorly in most companies relocating to other countries [3]. Moreover, some sociocultural certainties are seen as key dynamics disturbing businesses and are capable in reducing business leader's innovation and capabilities for successful business start-up.

Small and Medium Enterprise Financing and Sustainability

The success of every business is dependent on the level of funding and it relationship with external environment. Capital play significant role in the sustainability of small business because it serves as a principal factor in the acquisition of resources [10]. Though, in developing countries, Small businesses are faced with the problem of assessing required capital and this hinders their growth and sustainability. In Ghana, SMEs in Kumasi is constraint of high interest rate, lack of business certification, no financial security and pitiable business plan constitutes constraint to 
access fund [15]. Several government effort to resuscitate small and medium enterprises in Nigeria has not yield any good result due to administrative bottleneck in obtaining soft loan from micro finance institution [18]. Micro-finance would only offer credit facilities to SMEs with a worthy financial records, security, sustainable performance, worthy rapport with the bank etc [35]. Despite the challenges facing SMEs to obtain credit facilities in Rwadan, there exist significant connection between microfinance credit and small business performance in respect of profitability, growth and expansion of capital base. However, the survival of small businesses depends on access to credit, Capital and favourable regulations which are essential necessity to succeed in a business enterprise [19]. In her study [22] found a significant relationship between microcredit institutions and SME development in Anambra state of Nigeria. Inadequate collateral are the most difficult problem confronting the successes of Small-scale businesses in Nigeria [29]. These collateral requires by banks has made so many small and medium enterprises critically ill of fund thereby awaken their tendency of depending wholly on personal savings and inheritance. Among other sources of business financing, supplier credit and personal savings are classified as best sources of capital for small trades in West Africa [10]. Access to finance by SMEs indicated optimistic relationship with economic growth while Interest and Inflation rate indicated adverse and optimistic effect on economic growth [12]. SMEs in Algeria is fragile, as a result its contribution to job creation and economic development is grossly insignificant [8]. Similarly, poor government policies, incentives and tariff, sour state of infrastructure in Nigeria impinge on SMEs, thereby making it very fragile to contribute meaningfully to economic growth and output not significant [13]. SMEs growth is quite influence to an extent by government policies. Hence, formulation of favourable strategies that would facilitate the actualization of SMEs developmental programme is dependent on government policy across African countries as advocated [27]. Employing operative capital management mechanism would also help to upsurge sustainability of firms [25]. As organization strategy policy, working capital emphases on sustainable current assets and current liabilities such as cash and other payables. These assist business to measure its cash flow over time and provide procedures of meeting its short-term debt obligations as there may fall due. Angel financing provide a formidable source of human, financial and social investment in SME funding and sustainability in Nigeria [26] while the Studied on sustainability and company performance indicated that business performance enable sustainability and growth in terms of real GDP [7]. Therefore, since SMEs constitute considerable business operations that could easily drives needed economic expansion, its collaboration with critical stakeholders will assist achieve this objective. Moreover, sustainability of SMEs need to identify with the planet, people and profit. Notwithstanding, constant commitment of business in economic development is quite important in enhancing life of workers, contributing to domestic and global community well-being and operational sustainability [12].

Small and Medium Enterprises Accounting behaviour and challenges.

As a tool for effective decision making, accounting system has provided a plate form for management to moulding a successful business not only in terms of profitability but also ensuring that social responsibilities are carried out well appropriate. A review of existing body of researches discloses accurate accounting records help firm to track economic activities over time. Though the structure of the accounting system is documented but limited in one way or the other, these results to some author believing that accounting information and record keeping is insignificant to business growth and profitability enhancement. Increase in the number of SMEs in recent time could be linked to their positive reasoning in record keeping and several acquaintance with business key factor [30]. More emphasis was made on accounting data in the work of [9] due to its importance in providing accurate information that guide owner's decision. In their work, [11] also opined that profit planning requires assembly of information concerning past performance. SMEs project is aimed at profit maximization, expansion of economic scope of transaction and reduction in unemployment rate of a country. However, purchases and sales of goods is geared toward determination of break-even and providing a large of additional financial analyses built on accounting information. Several studies also shows that failure among SMEs could be shiftily credited to pitiable accounting system and owner's inexperience. In their study, the necessity and significance of accounting record to an entity, [22] Pointed that management accounting information could be connected to the achievement or disappointment of SMEs. Though success and growth of small businesses are deeply anchored on the entrepreneur skills in addressing business challenges. Accounting system requires competent structure to provide precise information and controls of economy transactions [24]. SMEs owners lack needed skills to keep proper accounting records and more often maintain only cash book without recourse to the principle of double entry which constitute on their part time consuming and unnecessary waste of resources [30]. Several factor impinge accounting system of SMEs such as financial inadequacy, poor managerial skill, inadequate infrastructure among others are critical to SMEs set back [32]. In their study, [1] identified ten challenges facing accounting practice of SMEs in Nigeria to include; disregard to training, poor managerial skill, careless book keeping method amongst others. Majority of SMEs keep record in memory for the fear of being assess by tax authority and other business regulatory agencies [6]. The avoidance of proper books from transactions undertaken made it difficult to track transaction as they occur in the course of the business. Apparently, poor accounting system as pointed above results to business operators losing up pathway of their day-to-day economic transactions and could be challenging to provide needed explanation regarding expenses incurred and profits at accounting year end. A 
sound accounting system is characterised with books, records, vouchers, files and related supporting document resulting from the application of economic activities.

The concept of success in business is often infer to be performance irrespective of the economic situation facing such undertaking. In view of this, several investigations were carried out both within and outside Nigeria. The results provide reasonable revelation with respect to SMEs growth and sustainability in different economic background. In Malaysia for instance, investigation on the factors that influence in Growth Domestic Product (GDP) contribution by Small and Medium Enterprises (SME) was carried out. The study revealed that labour wages and net export are the key factors highly contributing to SME'S performance [5]. In Ghana, a similar investigation was also carried out to assess the contributions of small a medium sized enterprises. The result revealed that SMEs contribute massively to job creation, principally to those with educational background and rural settlement [27]. Extant literature have documented studies on SMEs, especially in developing economic. Some of these study provides conflicting ideas and concentrated more on economic growth while few examined firm growth. However, there have been scanty investigation to provide linear relationship between accounting behaviour of SMEs and its sustainability. This study therefore seek to examine accounting behaviour of SMEs with special emphasis on sustainability and growth in Nigeria, so as to establish whether they are able to contribute to economic growth and survive beyond speculations.

\subsection{Theoretical Framework}

The theory of Business enterprise - [33].

The theory considered the tangled but mismatched stimulus between business and the industry growth. The propounded believed that commercial need of industry has been over turn by machine making it possible for certainty, quantitative, accuracy and precision. Industrial growth has progressively conquer small business firms which was earlier organized in craft form and in recent time open an opportunity for production on a disjointed and mechanical form. Veblen maintained that Preceding the period of industrial growth, the only industries concern in significant investments were in shipping industry, banking and merchant firms whose main activity is giving out loans, making purchases and selling. Apart from the challenge of intensive start-up capital requirement on like in the banking and merchant firms, small and medium enterprises engage significantly in competitive selling and charge prices in a form that customers can afford thereby breaking the gap created by big industry in the facilitation of economic.

Enterprise Growth Theory - [34].

This theory provides the basis for industrial development and sustained economic growth of any society by evaluating the propensities of stable and steady growth of the performance level. Enterprise growth provide value addition to enterprise through optimization of the change speed between production factor and production result [25]. SMEs is regarded as the commonest type of business structure across the world and its contribution is significant toward economy sustainability. In the intensive competitive market, the survival and sustainability of enterprise is very pertinent and is depended on technology, product and originality possessed by the enterprise. Enterprise growth force is the ability of enterprise's to comprehend the expansion of quantity and improve the quality in future period as whereas deciding the prospect and expansion amount of enterprise advancement [20]. However, governments all over the country have realize the importance of strengthening SMEs and have formulated policies to encourage, support and fund its activity for the purpose of economy expansion and creation of jobs. This new trend has made it necessary for SMEs to maintain economic record of event so as to evaluate performance and justify their sustainability.

\section{Methodology}

The study used expository quantitative survey method which involves collecting of data from primary sources for the purpose of achieving the designed objectives. The criteria for selection in the study were entrepreneurs who has engaged in business for a preceding minimum period of five years and fulfilled business registration requirement as SMEs. A questionnaire was objectively developed, organised in two sections and were distributed to owners of SMEs using stratified random sampling techniques. The researchers identified major SMEs that are contributing to economic growth of the state such as agro-allied companies, steel companies and trading and service sector. These categories of businesses were selected and the researchers involved 120 SMEs in Calabar city of Cross River State who accepted to part take in the study. A proportion of 83 responses were collated and analysed using descriptive statistics, paired sample t-test and Pearson's product moment correlation analysis to test the hypotheses formulated and prove a form of linkages between the variables.

\section{Data Presentation and Results}

Table 1. Distribution of Responses on Accounting Behaviour and record keeping Of SMEs sustainability.

\begin{tabular}{llll}
\hline & Frequency & \% & Cumulative\% \\
\hline $\begin{array}{l}\text { No record on sale proceed and } \\
\text { expenditure }\end{array}$ & 15 & 18 & 18 \\
$\begin{array}{l}\text { Difficult to maintain the system } \\
\begin{array}{l}\text { Accounting record exposes } \\
\text { financial position of enterprises }\end{array}\end{array}$ & 18 & 48 & 66 \\
$\begin{array}{l}\text { Accounting system requires staff } \\
\text { than expected }\end{array}$ & 10 & 22 & 88 \\
\begin{tabular}{l} 
Total \\
\hline
\end{tabular} & 83 & 12 & 100 \\
\hline
\end{tabular}

Drawing from the opinion in table 1 above, accounting behaviour and record keeping showed that $18 \%$ agree to no record keeping to track daily sales and expenses. The descriptive result further revealed that $48 \%$ of the respondents believe that accounting record has several 
challenges including difficulty in putting in place measures for internal check. Furthermore, 22\% agree that accounting records exposes financial position of the enterprise and could give room to tax assessment. Similarly, $12 \%$ of the respondents also believe that having accounting system in place would increase the number of employee and could increase expenses given their revenue base.

Results:

Table 2. One-Sample Statistics.

\begin{tabular}{llll}
\hline & N & Mean & Std. Deviation \\
\hline No record on sale proceed & 83 & 2.6988 & 1.00892 \\
Difficult to maintain the system & 83 & 2.7229 & 1.02782 \\
Expose financial position & 83 & 2.9639 & .11074 \\
It require more staff & 83 & 2.9880 & .99322 \\
\hline
\end{tabular}

4 points Likert scale as "'strongly agree, agree, strongly disagree and disagree" was used in regards to accounting behaviours and record keeping of SMEs sustainability. The result using Table 2 indicates means and standard deviations each of the item. The greater mean score on a variable indicate a solid agreement. From these premise, respondents affirm that having accounting system in place requires more staff thereby increasing running cost of business over time.
This is not alone, respondents further revealed that accounting record expose economic transaction and provide avenue for tax assessment. Percentage of respondents also agree to no record keeping while some feel discourage to maintain accounting system resulting from the pains they undergo in keeping accounting records. The mean score are 2.9880, 2.9639 and standard deviation. 99322, 99381 respectively.

Table 3. One-Sample Statistics.

\begin{tabular}{|c|c|c|c|c|}
\hline & $\mathbf{N}$ & Mean & Std. Deviation & Std. Error Mean \\
\hline Access to credit & 83 & 2.6639 & .80115 & .08794 \\
\hline Profit is maximised & 83 & 2.8072 & .87594 & .09615 \\
\hline Motivate owners & 83 & 2.7349 & .98877 & .10853 \\
\hline Compulsory records keeping & 83 & 2.6145 & .98564 & .10819 \\
\hline
\end{tabular}

Using 4 points Likert scale as "strongly agree, agree, strongly disagree and disagree" in regards to accounting behaviours on growth of SMEs. The above result in Table 3 shows the means and standard deviations each of the item. The greater mean score on a variable indicate a firm agreement. From these perspective, respondents agree that accounting system assist SMEs to determine profit margin as whereas influencing them in the commitment of more resources and time. The mean score is 2.8072, 2.7349 and standard deviation. 87594, 109853 respectively, follow by access to credit facility and compulsory record keeping which was seen as not too lee to growth.

Table 4. Distribution of Responses on accounting practices and SMEs growth.

\begin{tabular}{llll}
\hline & Frequency & \% & Cumulative\% \\
\hline It provide access to credit facility at ease & 21 & 25 & 25 \\
Profit is maximised when records are kept & 32 & 39 & 64 \\
Motivate owners to maintain and keep record & 16 & 19 & 83 \\
Ensuring compulsory record keeping & 14 & 17 & 100 \\
Total & 83 & 100 \\
\hline
\end{tabular}

Table 4. above showed distribution of responses on accounting practices on SMEs growth. The descriptive result proved that $25 \%$ respondents believe that SMEs growth do not depend on credit facility from financial institution and loan out fit to finance its operation due largely to rigorous procedures involve in obtaining credit facility. The result also revealed that $39 \%$ of the respondents agree that accounting practice assist enterprise to ascertain their profit margin and provides opportunity for growth and sustainability. Furthermore, $19 \%$ believe that owners are motivate with the level of profit maximisation having a good accounting system in place. The result finally showed that $17 \%$ respondents believe that growth and sustainability of SMEs provide opportunity for compulsory accounting records.

Table 5. One-Sample Test.

\begin{tabular}{|c|c|c|c|c|c|c|}
\hline & \multicolumn{6}{|c|}{ Test Value $=2$} \\
\hline & \multirow{2}{*}{$\mathbf{T}$} & \multirow{2}{*}{ Df } & \multirow{2}{*}{ Sig. (2-tailed) } & \multirow{2}{*}{$\begin{array}{l}\text { Mean } \\
\text { Difference }\end{array}$} & \multicolumn{2}{|c|}{ 95\% Confidence Interval of the Difference } \\
\hline & & & & & Lower & Upper \\
\hline No record on sale proceed & 6.310 & 82 & .000 & .69880 & .4785 & .9191 \\
\hline Difficult to maintain the system & 6.408 & 82 & .000 & .72289 & .4985 & .9473 \\
\hline Expose financial position & 8.841 & 82 & .000 & .96386 & .7470 & 1.1807 \\
\hline It require more staff & 9.057 & 82 & .000 & .98795 & .7709 & 1.2050 \\
\hline
\end{tabular}


To test the hypothesis "Accounting behaviours have no significant effect on the sustainability of small and medium enterprises in Nigeria. The mean of those that agree are $2.9880,2.9639,2.6988$ and 2.7229 with standard error of .99322, .99381, 1.00892 and 1.02782 (83 out of 120$)$, the p-value of 0.000 indicates a significant relationship existing between accounting behaviours and SMEs sustainability. The t-statistics value as calculated is greater than table value given $0.05 \%$ significant level ( $t$-stat $<0.05$ ) we therefore reject the null hypothesis and the alternate accepted to show that accounting behaviours significantly affect sustainability of small and medium enterprises.

Table 6. One-Sample Test.

\begin{tabular}{|c|c|c|c|c|c|c|}
\hline & \multicolumn{6}{|c|}{ Test Value $=4$} \\
\hline & \multirow{2}{*}{$\mathbf{T}$} & \multirow{2}{*}{ df } & \multirow{2}{*}{ Sig. (2-tailed) } & \multirow{2}{*}{ Mean Difference } & \multicolumn{2}{|c|}{ 95\% Confidence Interval of the Difference } \\
\hline & & & & & Lower & Upper \\
\hline Access to credit & 7.549 & 82 & .000 & .66386 & .4889 & .8388 \\
\hline Profit is maximised & 8.396 & 82 & .000 & .80723 & .6160 & .9985 \\
\hline Motivate owners & 6.772 & 82 & .000 & .73494 & .5190 & .9508 \\
\hline Compulsory records & 5.680 & 82 & .000 & .61446 & .3992 & .8297 \\
\hline
\end{tabular}

The hypothesis is therefore "there is no significant relationship between accounting records and SMEs growth in Nigeria. The mean of those that agree is $2.6639,2.8072$, 2.7349 and 2.6145 with standard error of $.80115, .87584, .98877$ and .98564 (83 out of 120) and from the table, the p-value the p-value of 0.000 indicates a significant relationship existing between accounting practice on SMEs growth. The t-statistics value as calculated is greater than table value given $0.05 \%$ significant level ( $t$-stat $<$ 0.05 ) we therefore reject the null hypothesis and the alternate accepted to show that accounting practices significantly affect SME s growth.

Table 7. Distribution of responses on accounting behaviours and record keeping of SMEs sustainability.

\begin{tabular}{|c|c|c|c|c|c|c|c|c|c|c|c|c|c|c|c|c|c|c|c|c|c|}
\hline \multirow{2}{*}{$\begin{array}{l}\text { Account } \\
\text { Behaviours of } \\
\text { SMEs } \\
\text { Responses } \\
\end{array}$} & \multicolumn{4}{|c|}{$\begin{array}{l}\text { No Record on sales } \\
\text { proceed and } \\
\text { expenditure. }\end{array}$} & \multicolumn{4}{|c|}{$\begin{array}{l}\text { Difficult to Maintain } \\
\text { accounting system. }\end{array}$} & \multicolumn{4}{|c|}{$\begin{array}{l}\text { There is no need to } \\
\text { keep accounting } \\
\text { Records. }\end{array}$} & \multicolumn{4}{|c|}{$\begin{array}{l}\text { Accounting record } \\
\text { exposes financial } \\
\text { position. }\end{array}$} & \multicolumn{4}{|c|}{$\begin{array}{l}\text { Accounting system } \\
\text { requires staff than } \\
\text { expected. }\end{array}$} & \multirow[t]{2}{*}{ Total } \\
\hline & SA & $\mathbf{A}$ & D & SD & SA & $\mathbf{A}$ & D & SD & $\mathbf{S A}$ & $\mathbf{A}$ & D & SD & SA & $\mathbf{A}$ & D & SD & SA & $\mathbf{A}$ & D & SD & \\
\hline \multicolumn{22}{|l|}{ Welding work (3) } \\
\hline \multicolumn{22}{|l|}{ Super Market (3) } \\
\hline \multicolumn{22}{|l|}{ Poultry (4) } \\
\hline \multicolumn{22}{|l|}{ Tailoring (6) } \\
\hline \multicolumn{22}{|l|}{ Head Dressing (4) } \\
\hline Total & & & & & & & & & & & & & & & & & & & & & \\
\hline
\end{tabular}

Table 7. Continued.

\begin{tabular}{|c|c|c|c|c|c|c|c|c|c|c|c|c|c|c|c|c|c|c|c|c|c|}
\hline \multirow{2}{*}{$\begin{array}{l}\text { SMEs } \\
\text { sustainability } \\
\text { and growth. } \\
\text { Responses } \\
\end{array}$} & \multicolumn{4}{|c|}{$\begin{array}{l}\text { It provide access to } \\
\text { credit facility. }\end{array}$} & \multicolumn{4}{|c|}{$\begin{array}{l}\text { Profit is ascertain } \\
\text { when records are } \\
\text { kept. }\end{array}$} & \multicolumn{4}{|c|}{$\begin{array}{l}\text { Owners are motivated } \\
\text { when business record } \\
\text { successes. }\end{array}$} & \multicolumn{4}{|c|}{$\begin{array}{l}\text { Enhancement of Record } \\
\text { and sustainability of } \\
\text { business. }\end{array}$} & \multicolumn{4}{|c|}{$\begin{array}{l}\text { It improves continuous } \\
\text { monitoring and control } \\
\text { of internal system. }\end{array}$} & \multirow[t]{2}{*}{ Total } \\
\hline & SA & $\mathbf{A}$ & D & SD & SA & $\mathbf{A}$ & D & SD & SA & $\mathbf{A}$ & D & SD & SA & $\mathbf{A}$ & D & SD & SA & $\mathbf{A}$ & D & SD & \\
\hline \multicolumn{22}{|l|}{ Fishery 3} \\
\hline \multicolumn{22}{|l|}{ Super Market 3} \\
\hline \multicolumn{22}{|l|}{ Poultry 4} \\
\hline \multicolumn{22}{|l|}{ Tailoring 6} \\
\hline Head Dressing 4 & & & & & & & & & & & & & & & & & & & & & \\
\hline Total 20 & & & & & & & & & & & & & & & & & & & & & \\
\hline
\end{tabular}

\section{Conclusion and Recommendations}

Accounting behaviour of any entity be it government or private, provide confidence and build up more opportunities for investors. Any enterprise whose transaction are not documented will never know its worth in term of assets and liabilities, therefore, accounting behaviour mirrored the sustainability and growth of an entity. Small and medium enterprises contribute significantly in growing domestic market through creation of jobs and re-distribution of income among house-holds and firms. In this study, the challenges of SMEs was examined as to determine whether the behaviours of the SMEs and accounting practices constitute the reason why they short-lived. We developed and distributed questionnaire from where responses were collated and analysis using descriptive statistics, paired sample t-test and Pearson's product moment correlation analysis. It was observed from the result that SMEs do not maintain accounting record. This attitude of operating without accounting system to track daily economic transaction is connected to them not exposing their financial position for assessment by revenue authority. This singular reason is 
said to be why they see it difficult to maintain accounting system despite the fact that it may improve efficiency and assist them in the evaluation of performance. The result also revealed that if they exist accounting system, it will amount to additional employee cost. We also looked at the sustainability and growth of SMEs in a given accounting behaviour, the result showed that accounting behaviour of SMEs determine profitability positioning and could enhance internal control system. This imply that accounting behaviour of SMEs determine its sustainability and growth, so effort towards maintaining stable growth should embrace accounting system with respect to enterprise growth theory perspective. SMEs being the largest economic sector contributing greatly to Nigeria GDP has the capacity to create reasonable jobs and reduction of crime rate in calabar, Nigeria. Consequently upon the findings and conclusion, the study recommended that government and owners of SMEs need collaboration in the area of training and capacity building (on business record) which may go a long way in improving the social economic of the state. Small and medium enterprises should also develop business record habit in their economic transaction as it will enhance performance measurement over time.

\section{References}

[1] Ademola, I. S., \& Michael, A. A. (2012). Small scale businesses as a remedy to unemployment problem in Nigeria. International Journal of Scientific \& Engineering Research, $3(11), 1-6$.

[2] Agwu, O \& Emeti, C (2014). Issues Challenges, and prospects of small and medium scale enterprise in Port Harcourt City, Nigeria. European Journal of sustainability Development. 3(1), 101-114.

[3] Akuru, U \& Okoro, O (2011). Economic implications for constant power outages on SME in Nigeria. Journal of Energy in Southern Africa. 25 (3), 47-61.

[4] Aremu, M. A. \& Adeyemi, S. L (2011) Small and Medium Scale Enterprises as A Survival Strategy for Employment Generation in Nigeria. Journal of Sustainable Development. 4 (1).

[5] Arunagiri, S., Kalaippiriya, K., Krishaa, R \& Vithya (2015). A study on Small and Medium Enterprise (SMEs) growth domestic product contribution from Malaysian Economic perspective. IOSR Journal of Business and management. 17(6), 62-69.

[6] Aryeetey, E., Baah-Nuakoh, A., Duggleby, T., Hettige, H., \& Steel, W. F. (1994). Supply and Demand for Finance of SmallScale Enterprises in Ghana. World Bank Discussion Paper No. 251. Washington, D.C.: The World Bank. http://dx.doi.org/10.1596/0-8213-2964-2

[7] Bassey, E., Ejabu, F., \& Atu, O (2017). Effects of environmental audit and economic sustainability of quoted manufacturing firms in Nigeria. European Journal of Accounting, Auditing and Finance research. 5(10), 39-53.

[8] Bouazza, A. (2015). Small and Medium Enterprises as an effective sector for economic development and Employment creation in Algeria. International Journal of Economics, commerce and management. 3(2), 2348-0386.

[9] Biryabarema, E. (1998). Small Scale Business and Commercial Banks in Uganda. Kampala: Makerere University Press.

[10] Boateng. A, Muhammed. D \& Abdulrahman (2013). Micro small-size enterprise and bank credit: Evidence from West Africa. Journal of emerging market finance, 12, 129-150.

[11] Copeland, R. M., \& Dascher, P. E. (1978). Managerial Accounting. New York, NY: John Wiley.

[12] Crals, E., \& Vereek, L. (2004) Sustainable Entrepreneurship in SMEs: Theory and Practice. Poster presented at the 3rd Global Conference on Environmental Justice and Global Citizenship, Copenhangen, Denmark, 12th - 14th February. 8.

[13] Eze, T \& Okpala, C (2015). Quantitative analysis of the impact of small and medium scale enterprises on the growth of Nigeria Economy (1993-2011). International Journal of development and emerging economics. 3 (1), 26-38.

[14] Franca, N. C. (2013). The impact of micro finance credit institutions on the development of small and medium enterprises in Anambra state. IOSR Journal of Business and Management, 14(5), 75-81.

[15] Francois, M., Etornam, K., Patience, A., \& Albert, K. (2017). Accessing determinants of financial constraints on small and medium enterprises in Kumasi metropolis, Ghana. Journal of Business and Economic Development, 2(4), 198-203.

[16] Gbandi. E \& Amissah. G (2014). Financing options for small and medium enterprises in Nigeria. European scientific Journal, 10(1), 1857-7431.

[17] Juliana, A. O. (2013). Small scale industries and rural development in Edo State, Nigeria. Journal of Educational and Social Research, 3(9), 25-33.

[18] Kanayo, O., Jumare, F., \& Nancy, S. (2013). Challenges of microfinance access in Nigeria: Implication for entrepreneurship development. Mediterranean Journal of Social Science, 4, 611-618.

[19] Laetitia, M., Shukla, J \& Luvanda, A. (2015). Microfinance and Business growth of Women Small and Medium Enterprises in Rwanda. European Journal of Accounting, Auditing and finance research. 3(11), 26-39.

[20] Li, Zhicheng \& Diao, Zhaofeng. (2003). On Business Growth Force and Its Generating Mechanism. Journal of Wuhan University of Technology (Information \& Management Engineering). 25(5), 86-89.

[21] Llegbinosa, I \& Jumbo (2015). Small and Medium Enterprise and Economic Growth in Nigeria (1975-2012). International Journal of Business and management. 10(30), 1833-8119.

[22] Mitchell, F., Reid, G., \& Smith, J. (1998). A Case for Researching Management Accounting in SME's. Management Accounting: Magazine for Chartered Management Accountants, 76, 30-33.

[23] Mitchelmore, S., \& Rowley, J. (2013). Entrepreneurial competencies of women entrepreneurs pursuing business growth. Journal of Small Business and Enterprise Development, 20, 125-142.

[24] Mao Huiyuan (2009). Review on enterprise growth theories. International Journal of business and management. 4(8), 20-23. 
[25] Moses, O \& Adebisi. J (2015). Small business financing in Nigeria. An investigation of the angel option. Canadian Social Science, 9(2), 98-103.

[26] Muriithi, S. (2017). African small and medium Enterprises (SMEs) contributions, challenges and solutions. European Journal of Research and reflection in management Science. 5(1), 2056-5992.

[27] Ntiamoah, E., Opoku, B., Abrokwah, E., Baah-Frimpong, G \& Agyei-Sakyi, M (2014). Assessing the contributions of small and medium sized enterprises to Ghana's Economic. International Journal of economic, commerce and management. 2(2)2348-0386.

[28] Okpara, J. O. (2011). Factors constraining the growth and survival of SME in Nigeria: Implications for poverty alleviation. Management Research Review, 34, 156-171.

[29] Olaoye, C. O (2012) Fundamental of Financial Accounting 2 Ado-Ekiti: Jehovah-Jireh Publishers.

[30] Olson, O., Blomskvisk, M., Dergard, J., \& Jonsson, C. (2004). Accounting and Entrepreneurship: A Review and Discussion of the Scientific Literature. Paper Presented at the 4th AsiaPacific Interdisciplinary Research in Accounting Conference. 4-6, Singapore.

[31] Opara. J (2011). Factors constraining: Implications for poverty alleviation. Management Research Review 34, 156-171.

[32] Samson. A, Mary. J, Yemisi. B \& Erekpitan. I (2012). The impact of working capital management on the profitability of small and medium scale enterprises in Nigeria. Research Journal of Business management, 6(2), 61-69.

[33] Veblem, T. (1904). The theory of business enterprise. New York, Charles Scribner's sons. pp 20-65.

[34] Yang, Du. (1996). Enterprise Growth Theory. Beijing: China Renmin University Press.

[35] Zair. Z \& Zaima Z (2013). Difficulties in securing and medium enterprises (SME). Journal of Advanced Management Science, 1, 354-357. 